Finanse, Rynki Finansowe, Ubezpieczenia nr 5/2017 (89), cz. 1

\title{
Loan loss provisions in Polish banking sector
}

\author{
Joanna Rachuba, Tran Thi Thu Hoai*
}

\begin{abstract}
The following study concerns two main issues. To begin with, we review the research on the impact of bank-specific variables and macroeceonomic determinants of loan loss provisions. Furthermore, the topic of income smoothing is reviewed. Lastly, we consider the relation of LLP to the financial variables: assets, loans and net banking income. Our sample consists of commercial banks and cooperative banks in Poland in the period of 2008-2015. We found that the average ratio of LLP to assets is more stable in cooperative banks than in commercial banks. Moreover, the analysis of average ratio of LLP to loans showed that cooperative banks are characterized by a gradual rise since 2010 and a sharp increase in 2015 . In comparison, in commercial banks since 2010 we can see a slight decline in relation of LLP to loans. According to our findings, the study of the average level of LLP compared to net banking income shows that in cooperative banks the share of LLP in net banking income is increasing for the period of 2008-2014 to about 7\%, but after an intense growth in 2009, in 2010 and 2011 the banking sector recorded a significant fall in LLP share in net banking income. After 2011 commercial banks have stabilized the relation of LLP to net banking income at the level of about $14 \%$.
\end{abstract}

Keywords: loan loss provisions; banking sector; cooperative banks

\section{Introduction}

The loan loss provisioning in financial institutions is significantly related to their safe operation and their potential growth in the future. It is therefore imperative to study the changes in loan loss provisions in relation to the modifications of other factors in banks, which allows policy makers to make financial forecasts and provide rational policies. For this reason, it is a well-researched topic. There is rapidly growing literature analyzing the factors which have an influence on loan loss provisions. In connection to this issue, several studies also examine the income smoothing.

This paper examines specific loan loss provisions in Polish cooperative banks. First the authors review the research conducted so far about the change and the effect of loan loss provisioning in different countries, economic conditions and types of banks. The authors particularly concentrate on the income smoothing research. Consequently, data is collected to study the fluctuation of loan loss provision over time in Polish cooperative banks, researching how provisioning varies under the influence of other factors, like assets, loan and

\footnotetext{
* mgr Joanna Rachuba, Institute of Finance, Faculty of Economics and Management, University of Szczecin, ul. Mickiewicza 64, 71-101 Szczecin, e-mail: joanna.rachuba@wneiz.pl; Tran Thi Thu Hoai, student in National Economics University of Vietnam, exchange student in Faculty of Economics and Management, University of Szczecin, email: hoaitran.160994@gmail.com.
} 
net income, in the period from 2008 to 2015. Moreover, the authors compare cooperative banks with the whole banking sector. Finally, a conclusion is reached and further avenues of research are suggested.

\section{Determinants of loan loss provisions}

There is rapidly growing literature about determinants of loan loss provisions. For instance, Isa et al. (2015) conducted research to find out factors of loan loss provisions in Malaysian commercial banks. They used data from 12 banks over 17 years, between 1997 and 2014, and applied the regression model method. In the regression model, they included independent variables, such as non-performing loan, interest income, or net profit, and other macroeconomic variables, such as GDP. The researchers gave a supposition that interest income, the amount of loans and credit risk management have a positive impact on loan loss provisions, but non-performing loan, net profit and GDP affect LLP negatively. Similarly, Soedarmono et al. (2017) further examined whether loan loss provisioning in Islamic banks is procyclical, by using a sample of 146 Islamic banks studied in the years 1997 to 2012 . They put forward a claim that loan loss provisions in Islamic banks are generally procyclical. To be more specific, loan loss provisions drop when the economy is stronger and provisioning increases when the economy goes into recession. In addition, the researchers also concluded that Islamic banks provisioning behaviour might deepen the economic recession because the growth in loan loss provision leads to a decline in economic growth. On the other hand, Skała (2015) analysed 179 commercial banks in 11 Central European countries over the period 2004-2012. Skała argued that Central European banks' reserve-making behaviour is procyclical with respect to national business cycles. To be more specific, in the economic downturn Central European banks create additional reserves, leading to higher loan loss provisions. What is more, Floro (2010) used a database of banks in the Philippines from 2001 to 2009 to examine how the bank capital influences the loan loss provisions. The author found a strong and negative relationship between capital and loan loss provision. However, in contrast to other research in the same topic, the author found that there is a non-linear relationship between loan loss provisions and the economic cycle. Therefore, banks must understand the importance of strengthening the supervisory oversight of financial institutions, with a view to avoiding the tendency to excessive risk-taking. Moreover, Boulila Taktak et al. (2010) researched 66 Islamic banks for the period from 2001 to 2006 and the results show that lower capital ratio is connected to higher loan loss provision. This result supports the statement that well-capitalized Islamic banks engage in less risky activities, respecting profit and loss sharing principles in contrast to conventional banks. GDP is not statistically significant, indicating that business cycle does not affect current loan loss provision decisions of banks.

According to some authors, banks usually postpone loan loss provisions or reserve much lower than standard LLP, until a cyclical downturn appears. Specifically, Laeven 
and Majnoni (2003) provided some new empirical evidence that stresses the importance of making loan loss provisioning by analysing data from the US banks, from 1988 to 1999 . The econometric evidence shows that banks usually tend to delay provisioning. It is consistent with findings described by Angklomkliew et al. (2009), who presented evidence on the development of loan loss provision in Asia. In the wake of the Asian financial crisis, most Asian banks considered stricter provisioning practices and began the process of converging with international accounting standards. However, they had just had lower levels of provisioning and reserves for loan losses, and numerous systems impose additional requirements concerning provisions. A number of jurisdictions also adopted discretionary measures to increase provisioning in a favourable macroeceonomic environment in response to rising levels of risk. The results presented by Angklomkliew et al. demonstrate that levels of provisioning and reserves over the past few years appear to be higher, and banking systems are more resilient now than before the Asian financial crisis a decade ago. Cortavarria et al. (2000) confirmed that provisioning is a significant element of bank risk management system. From a macroeconomic perspective, their results indicate that many non-G-10 countries undertake measures against credit fail with the use of non-performing loans and provisions.

\section{Income smoothing}

The second part of the literature review concerns the income smoothing. Indeed, most authors concluded that banks use loan-loss provisions to smoothen income.

For example, Bouvatier and Lepetit (2012) conducted their study on the basis of financial statements data from five different geographical areas: Europe, Japan, the United States, Central and South America, South and East Asia, from years 1995 to 2008. By regression panel-data, this study provides confirmatory evidence that backward-looking provisioning practices amplify the cyclicality of bank lending, with a stronger impact for emerging countries. Moreover, the results show that the non-discretionary component of LLP has a negative and significant effect on growth in bank lending in all considered countries, except for Japan. A backward-looking provisioning system implies that during an economic upswing, banks tend to underestimate expected credit risk and, as a consequence, reduce non-discretionary LLP. Banks's incentives to grant new loans are therefore reinforced, since lending costs are understated. On the other hand, sudden identification of problem loans during an economic downturn constrains banks to make non-discretionary loan loss provisions, which reduces their incentive to supply new credit. Likewise, Fonseca and González (2008) in their paper about determinants of bank income smoothing in the form of managing loan-loss provisions collected panel-database of banks from 40 countries. They researched possible determinants of income smoothing, such as the influence of investor protection, transparency in accounting disclosure, bank regulation and supervision, financial structure and financial development of a country. They confirmed the claim that neither income smoothing nor a difference in income smoothing between publicly and non-publicly traded 
banks is stable across countries. Results suggested that there is less bank income smoothing not only with the strength of investor protection, but also with the extent of accounting disclosure, restrictions on bank activities, and social or private supervision. Moreover, there is more income smoothing with market orientation and development of a country's financial system. Correspondingly, Abou-el-Sood (2012) compared income smoothing in the precrisis and the after-crisis period. The author collected a sample of 878 US bank holding companies over the period from 2001to 2009 to find strong evidence of income smoothing behaviour. Abou-el-Sood (2012) contrasted the pre-crisis period of 2002-2006 with the crisis period of 2007-2009 to find out the difference in the use of loan loss provisions and the change of smooth income. One of important conclusions of her research is that loan loss provisions are significantly affected by income smoothing incentives. Secondly, banks use income smoothing incentives to delay the provisioning process during recessionary periods, giving rise to procyclicality concerns. Moreover, during the pre-crisis boom period, banks tend to accelerate provisioning to smooth income downward. Similar to other studies, Pérez et al. (2011) investigated the impact of a change in the regulatory framework on loan loss provisions incentives to smooth income in Spain. Using the standard panel data econometric methodology, the authors found strong evidence of income smoothing through general and specific loan loss provisions among Spanish banks. But the smoothing is only present in the period from 1988 to 1999 , when banks did not apply statistical provision. On the contrary, for the period from 2000 to 2004, when banks had to set aside the statistical provision, there is no evidence of income smoothing. Therefore, it seems that when banks are offered a transparent smoothing mechanism, they stop smoothing profits in a non-transparent way. Furthermore, Skała (2015) conducted research to find out that commercial banks from Central Europe use loan-loss provisions to smooth income by taking advantage of periods of higher profitability to build reserve buffers. Research findings lend support to the claim that Central European banks build reserves when their earnings are high. Finally, Boulila Taktak et al. (2010) examined issues about income smoothing practices in Islamic banking sector. According to the authors, Islamic banks offer a unique environment to test income smoothing, compared to conventional banks' activities in many other countries. This study is based on a sample of 66 Islamic banks over the period of 2001-2006, and it has detected that numerous Islamic banks resort to income smoothing practices. However, a surprising result indicates that managers of Islamic banks do not use loan loss provision to smooth their performance.

In conclusion, the research summarized above shows that loan loss provisions vary depending on a country, economic period, and a type of bank. Therefore, in the next part, the authors will examine the performance of loan loss provisions in Polish cooperative banks from 2008 to 2015 . 


\section{Data analysis}

The sample consists of the banking sector (with a specification of cooperative banks) in Poland. The study focuses on the period of eight years, between 2008 and 2015. We use specific bank variables: the level of LLP, loans, assets and banking net income. Data is collected from annual banking sector reports, which are published by Polish Financial Supervision Authority.

Figures 1-3 show the comparison between the average characteristics for cooperative banks and the banking sector, which is mostly represented by commercial banks.

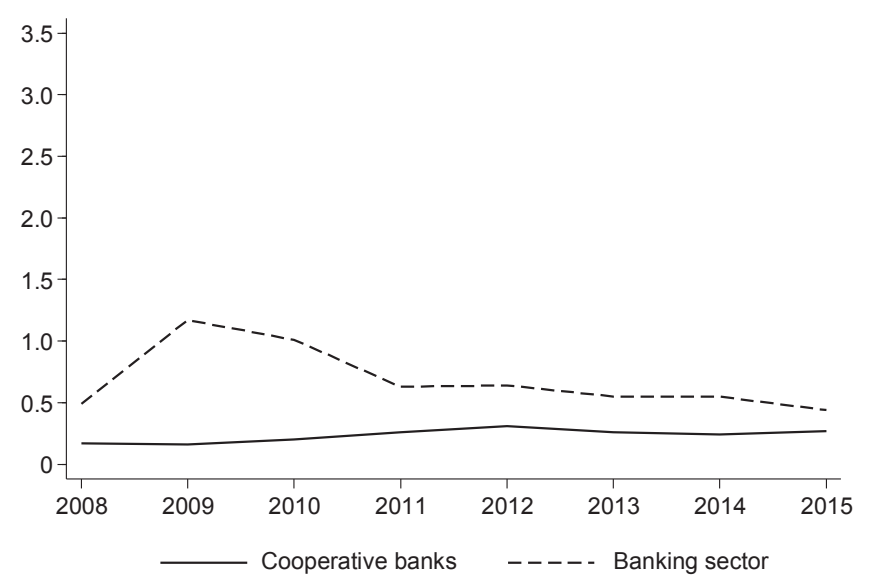

Figure 1. The average ratio of LLP to assets (\%)

Source: own elaboration.

Figure 1 provides the representation of the evolution of LLP share in assets. The level of loan loss provisions, in comparison to assets in cooperative banks is relatively steady for the period of 2008-2015. It means that the activity of cooperative banks is probably less procyclical than that of commercial banks. The graph highlights that cooperative banks did not raise the level of LLP in relation to assets as a result the global financial crisis after 2007. These trends are not the same in the banking sector. Commercial banks are characterized by a rapid growth of LLP share in assets in 2009. After this period and a drop in 2010, the average ratio of LLP to assets in banking sector is stabilizing and moves within a range $0.4-0.6 \%$. Figure 2 shows the average relation of LLP share to loans. There is a gradually rise in cooperative banks since 2010. The exception is a sharp increase in 2015, which probably was caused by bankruptcy of one of cooperative banks. Finally, there was a rapid rise in 2009 in the banking sector. It could be interpreted as a reaction to the global financial crisis. Since 2010 there is a decline in commercial banks in relation of LLP to loans, which could suggest an improvement in the loans' quality. 


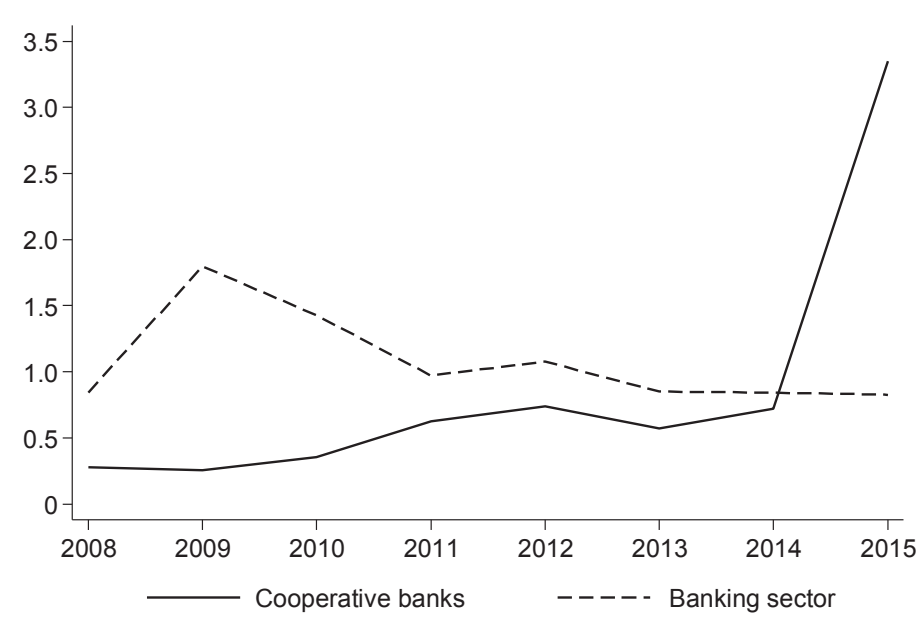

Figure 2. The average ratio of LLP to loans (\%)

Source: own elaboration.

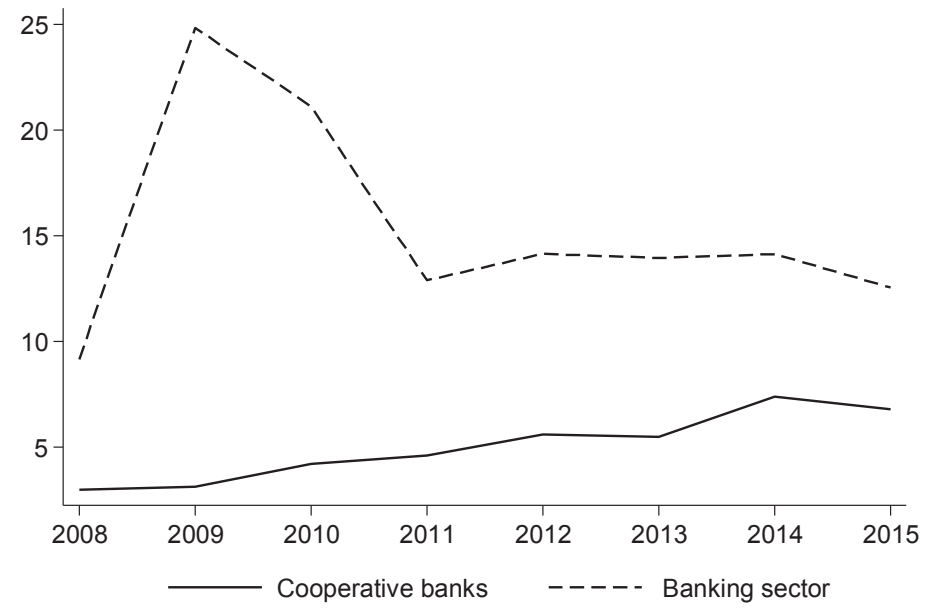

Figure 3. The average ratio of LLP to net banking income (\%)

Source: own elaboration.

Figure 3 provides an overview of the average ratio of LLP to net banking income in banking sector and cooperative banks. In cooperative banks we can see a gradual increase in LLP share in net banking income, but in 2015 we observe a slight fall. In contrast, the banking sector represents a greater variation. In 2009 there was an intense growth in LLP share in net banking income, which later, from 2010 to 2011 halved from about $25 \%$ to about $12-13 \%$. After this period, the average ratio of LLP to net banking income levelled off with 
insignificant drop in 2015. At the end of 2015 the average ratio of LLP to net banking income was almost doubled for the banking sector compared to cooperative banks.

\section{Conclusions}

To sum up, the results of the previous research show that LLP is connected with bank-specific variables, such as the growth of lending or the growth of assets, and macroeconomic factors, such as the growth of GDP or the economic cycle. To be more specific, LLP usually decreases when the economy goes up, and increases during the economic downturn. Moreover, banks usually use loan loss provisions to smoothen income. Some authors analyse the incentives of income smoothing by LLP or compare income smoothing tendency during pre-crisis and after-crisis period.

Our empirical results show that there is a difference in loan loss provisions policy carried out by the whole banking sector and cooperative banks in Poland for the period of 2008-2015. We analyse the average ratio of LLP to assets, LLP to loans and LLP to net banking income. Our main findings show that cooperative banks have more stable average LLP share in assets than commercial banks and an increasing relation of LLP in loans compared to banking sector. In addition to this, the average ratio of LLP to net banking income in cooperative banks is about $14 \%$, which means that it is double than the level of LLP to net banking income in commercial banks.

\section{References}

Abou-el-Sood, H. (2012). Loan loss provisioning and income smoothing in US banks pre and post the financial crisis. International Review of Financial Analysis, 25, 64-72.

Angklomkliew, S., George, J., Packer, F. (2009). Issues and developments in loan loss provisioning: the case of Asia. BIS Quarterly Review. Retrieved from: http://www.bis.org/publ/qtrpdf/r_qt0912h.htm.

Becchetti, L., Ciciretti, R., Paolantonio, A. (2016). The cooperative bank difference before and after the global financial crisis. Journal of International Money and Finance, 69, 224-246.

Beck, T., Degryse, H., De Haas, R., Van Horen, N. (2014). When Arm's Length Is Too Far: Relationship Banking over the Business Cycle. EBRD Working Paper 169. Retrieved from: https://www.dnb.nl/binaries/Working\%20 Paper\%20431_tcm46-309756.pdf.

Boulila Taktak, N., Zourari, S.B.S., Boudriga, A. (2010). Do Islamic banks use loan loss provisions to smooth their results? Journal of Islamic Accounting and Business Research, 2 (1), 114-127.

Bouvatier, V., Lepetit, L. (2008). Banks' procyclical behaviour: Does provisioning matter? Journal of International Financial Markets, Institutions \& Money, 18, 513-526.

Bouvatier, V., Lepetit, L. (2012). Effects on loan loss provisions on growth in bank lending: Some International comparisons. International Economics, 132, 91-116.

Bouvatier, V., Lepetit, L. (2012). Provisioning rules and bank lending: A theoretical model. Journal of Financial Stability, 8, 25-31.

Cappiello, L., Kadareja, A., Kok Sørensen, Ch., Protopapa, M. (2010). Do bank loans and credit standards have an effect on output? A panel approach for the euro area. ECB Working Paper 1150. Retrieved from: https://www. ecb.europa.eu/pub/pdf/scpwps/ecbwp1150.pdf.

Cortavarria, L. et al. (2000). Loan review, Provisioning and Macroeconomics Linkages. IMF Working Paper WP/00/195. Retrieved from: https://www.imf.org/external/pubs/ft/wp/2000/wp00195.pdf. 
Ferri, G., Kalmi, P., Kerola E. (2014). Does bank ownership affect lending behavior? Evidence from the Euro area. Journal of Banking and Finance, 48, 194-209.

Floro, D. (2010). Loan Loss Provisioning and the Business Cycle: Does Capital Matter? Evidence from Philippine Banks. BIS Working Paper. Retrieved from: http://www.bis.org/repofficepubl/arpresearch201003.07.pdf.

Fonseca, A.R., Gonzáles, F. (2008). Cross-country determinants of bank income smoothing by managing loan-loss provisions. Journal of Banking \& Finance, 32, 217-228.

Isa, M.Y.M. et al. (2015). Determinants of loan loss provisions of commercial banks in Malaysia. Research Gate. Retrieved from: https://www.researchgate.net/publication/273766261_Determinants_of_loan_loss_provisions_of_commercial_banks_in_Malaysia.

Laeven, L., Majnoni, G. (2003). Loan loss provisioning and economic slowdowns: too much, too late? Journal of Financial Intermediation, 12, 178-197.

Pérez, D., Salas-Fumás, V, Saurina J. (2011). Do dynamic provisions reduce income smoothing using loan loss provision? Banco De Espana Documentos de Trabajo 1118. Retrieved from: http://www.bde.es/f/webbde/SES/ Secciones/Publicaciones/PublicacionesSeriadas/DocumentosTrabajo/11/Fich/dt1118e.pdf.

Skała, D. (2015). Income Smoothing and Procyclicality of Loan Loss Provisions in Central European Banks. International Finance, 1 (18), 25-46.

Soedarmono, W., Pramono, S.E., Tarazi, A. (2017). The procyclicality of loan loss provisions in Islamic banks. Research in International Business and Finance, 39, 911-919.

\section{REZERWY NA STRATY KREDYTOWE W POLSKIM SEKTORZE BANKOWYM}

Streszczenie: Wiodącymi tematami podjętymi w artykule jest analiza dwóch obszarów badawczych występujących w literaturze. W pracy zostały zaprezentowane badania dotyczące wpływu zmiennych zarówno wewnątrzbankowych, jak i makroekonomicznych na kształtowanie się poziomu rezerw na straty kredytowe. Ponadto przedstawiono wnioski z analiz literaturowych dotyczących wygładzania dochodów. Część empiryczna została przeprowadzona w oparciu o próbę badawczą obejmującą sektor bankowy, z wyszczególnieniem sektora banków spółdzielczych w Polsce w latach 2008-2015. Pozyskane zmienne finansowe obejmują: aktywa ogółem, kredytyw ogółem oraz wynik bankowy netto. Na podstawie analizy danych stwierdzono, iż średni udział odpisów na rezerwy kredytowe względem aktywów jest bardziej stabilny w bankach spółdzielczych niż w bankach komercyjnych. Ponadto, badanie średniej relacji rezerw na kredyty zagrożone do kredytów ogółem wykazało, że banki spółdzielcze charakteryzowały się stopniowym wzrostem udziału rezerw od 2010 roku, ze szczególnym wskazaniem na gwałtowne zwiększenie ich poziomu w 2015 roku. Natomiast w bankach komercyjnych od 2010 roku zauważalny jest niewielki spadek udziału rezerw na straty kredytowe w kredytach ogółem. Analizując przeciętny poziom rezerw na straty kredytowe w porównaniu do wyniku bankowego netto wykazuje się, że w bankach spółdzielczych udział rezerw w wyniku bankowym netto wzrastał w latach 2008-2014 do poziomu ok. 7\%. Z kolei sektor bankowy po silnym wzroście w 2009 roku odnotował znaczny spadek rezerw na kredyty zagrożone w relacji do wyniku bankowego netto w latach 2010-2011, po którym nastąpiła jego stabilizacja na poziomie wynoszącym ok. 14\%.

Słowa kluczowe: rezerwy na straty kredytowe; sektor bankowy; bankowość spółdzielcza

\section{Citation}

Rachuba, J., Thi Thu Hoai, T. (2017). Loan loss provisions in Polish banking sector. Finanse, Rynki Finansowe, Ubezpieczenia, 5 (89/1), 497-504. DOI: 10.18276/frfu.2017.89/1-41. 